\title{
EFFECT OF FEE BASED INCOME AND OPERATIONAL COSTS ON PROFIT IN PT. SHARIA INDONESIAN PEOPLE'S BANK
}

\author{
Karlina ${ }^{1}$, Ikhwanuddin Harahap ${ }^{2}$, Windari ${ }^{3}$, Ali Hardana ${ }^{4}$ \\ ${ }^{1}$ IAIN Padangsidimpuan (Perbankan Syariah, FEBI, IAIN Padangsidimpuan) \\ ${ }^{2}$ IAIN Padangsidimpuan (Hukum Syariah, FEBI, IAIN Padangsidimpuan) \\ ${ }^{3}$ IAIN Padangsidimpuan (Perbankan Syariah, FEBI, IAIN Padangsidimpuan) \\ ${ }^{4}$ IAIN Padangsidimpuan (Ekonomi Syariah, FEBI, IAIN Padangsidimpuan) \\ karlina@gmail.com ${ }^{1}, \underline{\text { ikhwanuddinharahap@iain-padangsidimpuan.ac.id }}{ }^{2}$, wwindariok@gmail.com $^{3}$ \\ alihardana@iain-padangsidimpuan.ac.id $^{4}$
}

\begin{abstract}
ABSTRAK
Penelitian ini dilatar belakangi oleh menurunnya perolehan laba pada triwulan I-IV tahun 2017 yang diduga dipengaruhi oleh pendapatan khususnya pendapatan yang berasal dari jasa-jasa layanan (fee based income) dan biaya operasional. Tujuan dari penelitian ini adalah untuk mengetahui pengaruh fee based income dan biaya operasional terhadap laba pada PT. Bank Rakyat Indonesia Syariah baik secara parsial maupun simultan. Penelitian ini adalah penelitian kuantitatif, Teknik analisis data dengan analisis regresi linier berganda, dengan pengolahan data digunakan melalui program SPSS 23. Hasil Penelitian menunjukkan secara simultan variabel fee based income dan biaya operasional berpengaruh terhadap laba. Namun secara parsial variabel fee based income tidak berpengaruh terhadap laba. Sedangkan biaya operasional berpengaruh terhadap laba. Koefisien determinasi $\left(R^{2}\right)$ diperoleh $R^{2}$ sebesar 0,552 . Hal ini menunjukkan $55,2 \%$ setiap pertumbuhan laba dapat dijelaskan oleh variabel fee based income dan biaya operasional, sisanya $44,8 \%$ dijelaskan oleh variabel lain diluar penelitian ini.
\end{abstract}

Kata Kunci: Laba, Fee Based Income, dan Biaya Operasional

\section{ABSTRACT}

This research is motivated by decline in profitability in the first quarter of 2017 which is thought to be influenced by income, especially income derived from services (fee based income) and operating cost. The purpose of this study was to determine the effect of fee based income and operating cost on profits at PT. Bank Rakyat Indonesia Syariah both partially and simultaneously. This study is a quantitative study, data analysis techniques with multiple linear regression analysis, with data processing used through the SPSS 23 Program. The results of the study show that simultaneously fee based income and operating costs affect earnings. But partially, fee based income variables hasn't effect on earnings. While operating costs affect earning. The coefficient of determination $\left(R^{2}\right)$ obtained $R^{2}$ of 0,552 . This show that $55,2 \%$ of each profit growth can be explained by the variable fee based income and operating costs, the remaining $44,8 \%$ is explained by other variables outside this study.

Keywords: Profit, Fee based income and Operating costs 


\section{Journal of Sharia Banking}

\section{A. PENDAHULUAN}

Setiap tahun perusahaan di suatu negara terus bertambah, hal ini mengakibatkan terjadinya persaingan yang semakin ketat dalam dunia usaha. Salah satunya adalah perusahaan yang bergerak dibidang perbankan. Oleh karena itu, setiap perusahaan baik perusahaan besar maupun kecil harus mampu menghasilkan laba semaksimal mungkin. Menurut Undang-undang Nomor 10 Tahun 1998 yang dimaksud dengan bank adalah badan usaha yang menghimpun dana dari masyarakat dalam bentuk simpanan dan menyalurkannya ke masyarakat dalam bentuk kredit dan atau bentukbentuk lainnya dalam rangka meningkatkan taraf hidup rakyat banyak (Kasmir, 2008:3). Di Indonesia terdapat dua jenis bank yaitu bank konvensional dan bank syariah. Bank syariah adalah bank yang dalam aktivitasnya baik dalam penghimpunan dana maupun dalam rangka penyaluran dananya memberikan dan mengenakan imbalan atas dasar prinsip syariah (Direktorat Urusan Agama Islam dan Pembinaan Syariah, 2013:30).

Pada hakikatnya baik bank konvensional maupun bank syariah berorientasi pada laba (profit oriented). Namun yang membedakannya adalah bank syariah tidak mengenal istilah bunga dalam memberikan jasa kepada nasabah penyimpan maupun nasabah pembiayaan. Di bank syariah, keuntungan yang diberikan disesuaikan dengan prinsip syariah sesuai dengan hukum Islam.

Memperoleh keuntungan merupakan unsur yang paling penting bagi badan usaha. Laba atau keuntungan merupakan salah satu tujuan utama perusahaan dalam menjalankan aktivitasnya. Laba adalah selisih lebih pendapatan atas beban sehubungan dengan kegiatan usaha. Laba/rugi bank merupakan pengurangan biaya-biaya atas pendapatan yang diperoleh bank (Soemarso, 2013:245). Berikut tabel perolehan laba PT. Bank Rakyat Indonesia Syariah dalam triwulan dari tahun 2011-2018.

Tabel 1

Perolehan Laba PT. BRI Syariah

(Dalam Jutaan Rupiah)

\begin{tabular}{|l|l|l|l|l|}
\hline \multirow{2}{*}{ Tahun } & \multicolumn{4}{|c|}{ Triwulan } \\
\cline { 2 - 5 } & \multicolumn{1}{|c|}{ I } & \multicolumn{1}{|c|}{ II } & \multicolumn{1}{|c|}{ III } & \multicolumn{1}{|c|}{ IV } \\
\hline 2011 & 3.272 & 1.468 & 11.876 & 5.071 \\
\hline 2012 & 3.018 & 62.102 & 109.150 & 131.035 \\
\hline 2013 & 59.998 & 107.919 & 158.780 & 179.740 \\
\hline 2014 & 19.645 & 856 & 21.797 & 9.887 \\
\hline 2015 & 24.315 & 77.751 & 114.639 & 158.979 \\
\hline 2016 & 63.188 & 135.849 & 185.390 & 239.232 \\
\hline 2017 & 44.886 & 104.514 & 172.407 & 139.494 \\
\hline 2018 & 72.008 & 159.033 & 209.836 & 157.473 \\
\hline
\end{tabular}

Sumber: www.brisyariah.co.id

Berdasarkan tabel 1 di atas dapat dilihat bahwa perolehan laba mengalami fluktuasi. Khususnya untuk tahun 2014 dan 2017 laba mengalami penurunan yang cukup signifikan yaitu pada triwulan I-IV. Kemudian laba meningkat pesat pada 2015-2016 triwulan I-IV.

Secara umum terdapat dua sumber pendapatan bank umum yaitu pendapatan bunga (interest based income) dan pendapatan dari fee atas jasa-jasa yang diberikan (fee based income) (M. Sulhan dan Ely Siswanto, 2008:67).

Pada era sekarang ini, pendapatan perbankan tidak hanya difokuskan pada pendapatan usaha saja. Apabila hal ini dilakukan oleh sebuah bank, maka bank tersebut akan mengalami kesulitan pada tingkat 
profitabilitas yang akhirnya akan menyulitkan likuiditas bank tersebut. Untuk mengantisipasi hal tersebut, terdapat salah satu unsur pendapatan bank yang bisa membantu memperkuat bank pada posisi aman. Yakni pendapatan jasa bank lainnya. Filosofinya adalah bank memperoleh tambahan pendapatan dari pelayanan bank, bukannya dari exposure pembiayaan. Dengan demikian, tidak akan menambah posisi asset, akan tetapihanya menambah pendapatan bank di laporan rugi/laba (Sunarto Zulkifli, 2008:103).

Tabel 2

Perolehan Fee Based Income

PT. BRI Syariah (Dalam Jutaan Rupiah)

\begin{tabular}{|l|l|l|l|l|}
\hline \multirow{2}{*}{ Tahun } & \multicolumn{4}{|c|}{ Triwulan } \\
\cline { 2 - 5 } & \multicolumn{1}{|c|}{ I } & \multicolumn{1}{|c|}{ II } & \multicolumn{1}{|c|}{ III } & \multicolumn{1}{|c|}{ IV } \\
\hline 2011 & 48.216 & 33.348 & 56.663 & 95.708 \\
\hline 2012 & 41.767 & 74.433 & 108.458 & 169.071 \\
\hline 2013 & 35.569 & 74.426 & 107.172 & 138.109 \\
\hline 2014 & 14.876 & 32.758 & 53.847 & 83.454 \\
\hline 2015 & 30.022 & 66.200 & 101.920 & 143.118 \\
\hline 2016 & 37.748 & 69.926 & 104.541 & 145.202 \\
\hline 2017 & 31.311 & 68.824 & 114.192 & 174.495 \\
\hline 2018 & 223.183 & 231.106 & 324.353 & 528.444 \\
\hline
\end{tabular}

Sumber: www.brisyariah.co.id

Berdasarkan tabel 2 di atas, dapat diketahui bahwa fee based income menunjukkan perkembangan yang fluktusi.Pada tahun 2011-2014 triwulan I-III fee based income selalu menurun. Kemudian fee based income mengalami peningkatan pada 2015-2016 triwulan I-IV. Hingga pada 2017-2018 triwulan III-IV fee based income mengalami peningkatan.

Untuk meningkatkan keberhasilan bank syariah dalam menjalankan kegiatannya, tidak hanya ditentukan oleh pendapatan saja tetapi juga dipengaruhi oleh biaya yang dikeluarkan.
POINT Vol. 1, No. 2, Des 2020 Biaya yang dikeluarkan untuk menunjang kegiatan operasional bank syariah terdiri dari dua pos biaya yaitu, biaya operasional dan biaya non operasional. Biaya operasional adalah biaya pengelolaan kegiatan dan usaha bank baik langsung maupun tidak langsung (Frianto Pandia, 2012:20). Biaya operasional merupakan biaya yang memiliki peran besar di dalam mempengaruhi keberhasilan usaha bank syariah. Apabila biaya operasional bank syariah tidak ada maka kegiatan operasional bank syariah tersebut tidak akan berjalan lancar. Tetapi biaya operasional yang dikeluarkan juga akan menimbulkan menurunnya laba apabila biaya yang dikeluarkan bank syariah terlampau besar (M. Sulhan dan Ely Siswanto, 2008:69).

Tabel 3

Biaya Operasional PT. BRI Syariah

(Dalam Jutaan Rupiah)

\begin{tabular}{|l|c|l|l|l|}
\hline \multirow{2}{*}{ Tahun } & \multicolumn{4}{|c|}{ Triwulan } \\
\cline { 2 - 5 } & I & \multicolumn{1}{|c|}{ II } & III & IV \\
\hline 2011 & 161.174 & 321.646 & 501.240 & 756.464 \\
\hline 2012 & 206.167 & 404.972 & 619.323 & 903.896 \\
\hline 2013 & 238.945 & 516.913 & 828.222 & 1.224 .233 \\
\hline 2014 & 366.201 & 740.045 & 1.123 .459 & 1.549 .073 \\
\hline 2015 & 529.231 & 1.076 .234 & 1.598 .712 & 2.099 .198 \\
\hline 2016 & 545.503 & 1.061 .588 & 1.567 .395 & 2.403 .680 \\
\hline 2017 & 539.653 & 1.107 .933 & 1.703 .237 & 2.306 .185 \\
\hline 2018 & 567.483 & 2.103 .387 & 1.759 .777 & 2.377 .022 \\
\hline
\end{tabular}

Sumber: www.brisyariah.co.id

Berdasarkan tabel di atas menunjukkan bahwa biaya operasionalselalu meningkat setiap tahunnya. Biaya operasional tertinggi pada tahun 2016 triwulan IV.

Dari tabel 1, 2, dan tabel 3 di atas dapat diketahui bahwa teori tidak sejalan dengan data. Dimana pada tahun 2017 triwulan I sampai triwulan IV perolehan labapada PT. BRI Syariah mengalami penurunan yang cukup 
signifikan. Sementara pada saat itu fee based income meningkat pada triwulan III-IV, dan biaya operasional mengalami penurunan pada triwulan I dan IV. Seharusnya pada saat fee based income naik maka perolehan laba meningkat dan pada saat biaya operasional rendah maka laba akan meningkat. Namun hal ini tidak sesuai dengan teori yang ada.

\section{B. METODE}

Penelitian ini dilakukan di PT. Bank Rakyat Indonesia Syariah seluruh Indonesia melalui situs resmi PT. Bank Rakyat Indonesia Syariah (www.brisyariah.co.id). Penelitian ini adalah penelitian kuantitatif, sumber data dalam penelitian ini adalah data sekunder dengan bentuk data time series sebanyak 32 sampel. teknik pengumpulan data adalah dokumentasi yang ada di situs resmi www.brisyariah.co.id pada laporan keuangan PT. BRI Syariah Periode 2011-2018. Teknik analisis data dengan uji statistik deskriptif, uji asumsi klasik, uji hipotesis dan analisis regresi linier berganda, dengan pengolahan data digunakan melalui program SPSS 23.

Persamaan regresi linear berganda dapat dituliskan sebagai berikut:

$$
y=\alpha+b 1 F B I+b 2 B O+e
$$

Penjelasan :

$y=l a b a$

$\alpha=$ bila konstan

b1, b2 = koefisien regresi linear berganda

$\mathrm{FBI}=$ Fee Based Income

$\mathrm{BO}=$ biaya operasional

e = nilai error
Analisis regresi berganda digunakan untuk mengetahui keeratan hubungan antara variabel dependent (laba) dengan faktor-faktor yang mempengaruhinya atau variabel independent (Fee Based Income dan biaya operasional).

\section{HASIL DAN PEMBAHASAN}

Hasil koefisien determinasi $\left(R^{2}\right)$ diperoleh $R^{2}$ sebesar 0,552. Hal ini menunjukkan $55,2 \%$ setiap pertumbuhan laba dapat dijelaskan oleh variabel fee based income dan biaya operasional, sisanya $44,8 \%$ dijelaskan oleh variabel lain diluar penelitian ini. Secara parsial fee based income memiliki $t_{\text {hitung }}<t_{\text {tabel }}$ atau 1,042 < 1,699 hal ini menunjukkan bahwa variabel fee based income tidak berpengaruh terhadap laba, dan biaya operasional memiliki $t_{\text {hitung }}>t_{\text {tabel }}$ atau 3,806 $>1,699$ hal ini menunjukkan bahwa variabel biaya operasional berpengaruh terhadap laba. Secara simultan (bersama-sama) fee based income dan biaya operasional memiliki $F_{\text {hitung }}>F_{\text {tabel }}$ atau 17,900 > 3,33 hal ini menunjukkan bahwa secara bersama-sama fee based income dan biaya operasional berpengaruh terhadap laba.

Persamaan regresi lineer berganda dengan 2 variabel independen sebagai berikut :

$$
\begin{aligned}
& Y^{\prime}=a+b 1 X 1+b 2 X_{2} \text { atau } \\
& L B=a+b 1 F B I+b 2 \text { BO }
\end{aligned}
$$

\section{Keterangan:}

$$
\begin{aligned}
& \text { : nilai prediksi variabel } \\
& \text { dependen (laba) } \\
& \text { : Konstanta, yaitu nilai } Y^{\prime}, X_{1} \\
& \text { dan } X 2=0 .
\end{aligned}
$$


Karlina ${ }^{1}$, Hkhwanuddin Harahap ${ }^{2}$, Windari ${ }^{3}$, Ali Hardana ${ }^{4}$

b1 b2

: koefisien regresi, yaitu nilai peningkatan atau penurunan variabel

$Y^{\prime}$ yang

didasarkan variabel X1 dan X2

$\mathrm{FBI}$

BO

: fee based income

: biaya operasional

Berdasarkan output:

$L B=11376,479+0,118 \mathrm{FBI}+0,064 \mathrm{BO}$

Artinya :

Nilai konstanta (a) adalah $11.376,479$ ini dapat diartikan jika fee based income dan biaya operasional nilainya 0 , maka laba nilainya Rp11.376.479.000.

Nilai variabel fee based income (b1) bernilai positif yaitu 0,118 ; ini dapat diartikan bahwa setiap peningkatan fee based income sebesar Rp1.000.000 maka akan meningkatkan laba sebesar $\mathrm{Rp}$ 118.000. dengan asumsi variabel independen lain nilainya tetap.

Nilai variabel biaya operasional

bernilai positif yaitu 0,064 ; ini dapat diartikan bahwa setiap peningkatan biaya operasional sebesar Rp 1.000.000, maka akan meningkatkan laba sebesar Rp 64.000 dengan asumsi variabel independen lain nilainya tetap.

\section{PENUTUP}

\section{Kesimpulan}

Berdasarkan hasil penelitian, maka peneliti mengambil kesimpulan sebagai berikut:

Secara parsial fee based income tidak berpengaruh terhadap laba pada PT. Bank Rakyat Indonesia Syariah periode 2011-2018 dilihat dari besar thitung sebesar 1,042 < ttabel
POINT Vol. 1, No. 2, Des 2020 1,699 maka Ho diterima dan Ha ditolak artinya tidak terdapat pengaruh antara fee based income dengan laba.

Secara parsial biaya operasional berpengaruh terhadap laba pada PT. Bank Rakyat Indonesia Syariah periode 2011-2018 dilihat dari besarnya $t_{\text {hitung }}$ sebesar 3,806 $>t_{\text {tabel }}$ 1,699. Maka Ho ditolak dan Ha diterima artinya terdapat pengaruh antara biaya operasional terhadap laba.

Secara simultan (bersama-sama) fee based income dan biaya operasional berpengaruh terhadap laba pada PT. Bank Rakyat Indonesia Syariah periode 2011-2018 dilihat dari besar Fhitung sebesar 17,90 > Ftabel 3,33 maka Ho ditolak dan Ha diterima. Jadi dapat disimpulkan bahwa secara simultan fee based income dan biaya operasional berpengaruh terhadap laba.

\section{Saran}

Semoga adanya penambahan laba perbankan syariah.

\section{DAFTAR PUSTAKA}

Kasmir, Bank dan Lembaga Keuangan Lainnya, Jakarta: Rajawali Pers, 2013.

Kasmir, Dasar-dasar Perbankan, Jakarta: PT. RajaGrafindo Persada, 2008.

Kasmir, Manajemen Perbankan, Jakarta: Raja Grafindo Persada, 2004.

M. Nur Rianto Al Arif, Dasar-dasar Pemasaran Bank Syariah, Jakarta: Alfabeta, 2012. 
M. Sulhan dan Ely Siswanto, Manajemen Bank Konvensional dan Syariah, Malang: UINMalang Press, 2008.

Morissan, Metode Penelitian Survei, Jakarta: Kencana, 2012.

Mudrajat Kuncoro, Metode Riset Untuk Bisnis dan Ekonomi, Jakarta :Erlangga, 2009.

Murti Sumami dan Salamah Wahyuni, Metodologi Penelitian Bisnis, Yogyakarta: CV. Andi Offset, 2006.

Nurul Okima, Kamus Ekonomi, Surakarta: Aksara Sinergi Media, 2012.

Nur Asnawi dan Masyhuri, Metodologi Riset Manajemen Pemasaran, Malang: UINMaliki Press, 2011.

Rizal Aji Erlangga Martawireja, Ahim Abdurahim, Akuntansi Perbankan Syariah Teori dan Praktik Kontemporer, Jakarta: Salemba Empat, 2009.

Saifudddin Azwar, Metode Penelitian, Yogyakarta: Pustaka Pelajar, 2004.

Shella Fitri Aprillya, "Pengaruh Fee Based Income Terhadap Tingkat Return On Assets (ROA)", Skripsi:Universitas Pasundan Bandung, 2013.
Singgih santoso, Statistik multivarian Konsep, Aplikasi dengan SPSS, Jakarta: PT. Elex Media Komputindo, 2010.

Soemarso SR, Akuntansi Suatu Pengantar, Jakarta: Salemba Empat.

Sofyan Syafri Harahap, Teori Akuntansi, Jakarta: Rajawali Pers, 2008.

Sugiono, Metode Penelitian Bisnis, Bandung: Alfabeta, 2005.

Sugiyono, Metode Penelitian Kuantitatif Kualitatif dan R \& D, Bandung: Alfabeta, 2016.

Sukardi, Metodologi Penelitian Pendidikan: Kompetensi dan Prakteknya, Jakarta: PT. Bumi Aksara, 2008.

Sunarto Zulkifli, Panduan Praktis Transaksi Perbankan Syariah, Jakarta: Zikrul Hakim, 2003.

Sutan Remi Sjahdeini, Perbankan Syariah Produk-produk dan Aspek-aspek Hukumnya, Jakarta: Kencana Prenadamedia Group, 2014.

Undang-Undang Republik Indonesia No. 21 Tahun 2008, Tentang Perbankan Syariah.

Wiroso, Produk Perbankan Syariah, Jakarta: LPFE Usakti, 2009. 